Страхиња Р. СТЕПАНОВ* Универзитет у Новом Саду Филозофски факултет
Прегледни рад

Примљен: 09. 10. 2018. Прихваћен: 03. 12. 2018.

\title{
СРПСКИ ЈЕЗИК НА ВИСОКОШКОЛСКИМ УСТАНОВАМА У АУСТРИЈИ
}

\begin{abstract}
У реферату се аутор бави институционалним и програмским оквиром аустријских славистичких и преводилачких института, на којима се учи (и изучава) српски (тј. Б/X/C) језик, при чему ће најдетаљније бити предочена ситуација на Универзитету Карл Франц у Грацу. Покушаће се утврдити тенденција која прати уписну политику на факултетима где се може студирати српски језик. Тежиште рада биће на опису наставних планова и програма везаних за српски језик на аустријским институтима (фокус: Универзитет у Грацу). У закључном делу ће се изнети предлози и идеје везани за рад на лекторатима, те кораци које би наше надлежне институције требало да предузму како би се статус српског језика и српских лектората поправио и учинио успешнијим.

Кључне речи: лекторати српског језика у Аустрији (синхроно стање), српски језик на универзитетима у Аустрији, изазови лекторског позива, српски језик као страни.
\end{abstract}

1. Лекторати - општа слика. ${ }^{1}$ Према подацима које износи Весна Крајишник постоји неколико „модалитета изучавања српског језика на иностраним универзитетима у зависности од типа организације" (Крајишник 2014: 222): (i) конвенцијски лекторати, где постоји уговор између надлежних државних институција, (ii) лекторска настава српског језика у оквиру славистичких или других хуманистичких студија на иностраним универзитетима који преко јавних конкурса у иностранству бирају лекторски, односно наставнички кадар, те (iii) студијска настава српског језика, најчешће у

\footnotetext{
*strahinja.stepanov@ff.uns.ac.rs

${ }^{1} \mathrm{O}$ глотодидактичким, лингвокултуролошким аспектима учења и подучавања српског као другог или страног језика наводимо релевантне рецентније публикације: два зборника из 2007. год. - Савремене тендениије у настави језика и књижевности (пр. Јулијана Вучо) и Српски као страни језик у теорији и пракси: зборник радова (гл. ур. Милорад Дешић), те зборнике из 2011. Српски као страни језик у теорији и пракси: тематски зборник радова II (гл. ур. Весна Крајишник) и из 2016. Српски као страни језик у теорији и пракси: тематски зборник радова III (гл. ур. Весна Крајишник). У њима се, међутим, налазе и бројни радови који се тичу питања организације (наших) лектората у иностранству, избора лектора (и односа према њима) и сл.
} 
оквиру студија славистике, а „наставнички кадар чине држављани те земље који се професионално баве славистиком и бирају се према интерним правилима иностраног универзитета" (Крајишник 2014: 222). Ситуација са српским језиком на факултетима (институтима) у Аустрији има карактеристике свих трију модалитета, дакле и конвенцијског лектората и лекторске, одн. студијске наставе, при чему је Универзитет у Грацу та високошколска институција која је једина установила - за нас свакако најповољнији вид (сарадње) - конвенцијски лекторат, будући да је потписан споразум између Универзитета у Новом Саду (Филозофског факултета) и Универзитета у Грацу о ангажовању разменског лектора за српски језик.

\section{2. Српски језик на високошколским установама у Аустрији. Синоптичка (начелна) слика}

2.1. Пре него што се ближе упознамо са институционалним и програмским оквиром у којем се учи (и изучава) српски језик, истакнимо да се у академским круговима српски језик изучава под глотонимским ,акронимским кишобраном" - Б/X/C. Ако се позовемо на речи Ранка Бугарског, онда можемо констатовати како су српски и хрватски (и бошњачки/босански) и даље - у очима аустријске (и не само аустријске) славистике и лингвистике - варијанте ,званично упокојеног али у стварности још увек живог српскохрватског” (Бугарски 2016: 105). Тај се језик може учити као први (главни) језик у Аустрији на следећим славистичким департманима: Institut für Slawistik der Universität Wien (Универзитет у Бечу), Institut für Slawistik der Karl-Franzens-Universität Graz (Универзитет у Грацу) и Institut für Slawistik der Alpen-Adria Universität Klagenfurt (Универзитет у Клагенфурту). Донедавно се српски, тј. Б/Х/C могао изучавати и на Универзитету у Инзбруку (Institut für Slawistik der Universität Innsbruck), али је данас тамо могуће учити једино руски као први, док Б/Х/С, поред пољског, фигурира као други словенски језик, дакле са мањим бројем часова, сведен примарно на лекторске вежбе. ${ }^{2}$ Након окончања додипломских студија (Bachelorstudium Slawistik) знање рускога је на нивоу Б2, док други словенски језик (Б/Х/С или пољски) одговара нивоу А2(+)/Б1. Требало би, ипак, додати да и на мастер студијама у Инзбруку студенти могу да се одлуче за два изборна предмета који се баве Б/X/C језиком: на једном се даље проширује граматичко и лексичко знање са основих студија (Bosnisch / Kroatisch / Serbisch Ausbau des grammatischen und lexikalischen Wissens), док је други курс нешто специфичнији и тиче се одлика језика струке и науке (лингвистике, теорије књижевности и културо-

\footnotetext{
${ }^{2}$ Поред лекторских вежби, додуше, у Инзбруку се нуди и неколико изборних курсева везаних за Б/Х/C: одабране области из књижевности Б/Х/C аутора (Ausgewählte Bereiche der bos nisch-kroatisch-serbischen Literatur anhand einer ausgewählten Fragestellung / Einblick in die bosnisch-kroatisch-serbische Literatur und in die entsprechende Forschungslage) или одабране области из Б/X/C језикословља (Ausgewählte Bereiche der BKS Sprachwissenschaft) и преглед глаголског система Б/X/C-a (Das Verbalsystem des B/K/S).
} 
логије) Б/Х/С и његове рецепције (Wissenschaftssprache Bosnisch / Kroatisch / Serbisch: Entwicklung rezeptiver Kenntnisse im Umgang mit bosnischen/kroatischen/serbischen Fachtexten). Напослетку, на салцбуршкој славистици ${ }^{3}$ могу се студирати три словенска језика - руски, пољски и чешки - који се нуде и као први и као други словенски језик (у оквиру основних студија), тако да се Б/Х/C, који је некад био „помоћни” словенски језик, тамо више не изучава. ${ }^{4}$ Међутим, у Аустрији су веома развијени транслатолошки департмани, те се и на два таква института (Институт за теоријско и примењено преводилаштво у Грацу и Центар за преводилаштво у Бечу) такође може учити српски језик (тј. Б/X/C) у комбинацији с немачким и још једним (трећим) језиком. (О разликама у програмима између славистичких и транслатолошких института, посебно из лекторске позиције, биће више речи доцније.) Табеларно приказано, словенски се језици - а у оквиру њих издвајамо посебно српски (тј. тзв. Б/Х/C) - у Аустрији изучавају (као главни студијски смер) на следећим универзитетима (подаци према Аустријском славистичком друштву - Österreichischer Slawistenverband):

\begin{tabular}{|l|l|l|l|}
\hline Универзитети & $\begin{array}{c}\text { славистички } \\
\text { педагошки } \\
\text { см. }\end{array}$ & \multicolumn{1}{c|}{$\begin{array}{c}\text { институти } \\
\text { дипломски см. }\end{array}$} & $\begin{array}{c}\text { транслатолошки } \\
\text { институти }\end{array}$ \\
\hline Грац & Б/Х/С, РУ, СЛ & Б/Х/С, РУ, СЛ & С/Х/С, РУ, СЛ \\
\hline Инзбрук & РУ & РУ & РУ \\
\hline Клагенфурт & СЛ & Б/Х/С, РУ, СЛ & \\
\hline Салцбург & РУ, ЧЕ, ПО & РУ, ЧЕ, ПО & \\
\hline Беч & $\begin{array}{l}\text { Б/Х/С, РУ, СЛ, } \\
\text { ЧЕ }\end{array}$ & $\begin{array}{l}\text { Б/Х/С, БУ, ПО, ЧЕ, РУ, } \\
\text { СЛВК, СЛ, УК }\end{array}$ & Б/Х/С, РУ, ПО, ЧЕ \\
\hline
\end{tabular}

2.2. Структура славистичких студија. Аустријске славистике нуде, по правилу, као што се види из табеле, следеће врсте студија: додипломске (Bachelorstudium Slawistik) и мастерске (Masterstudium Slawistik), с тим што у већини случајева постоје и тзв. наставнички/педагошки смерови ${ }^{5}$ на основним и мастерским студијама (Bachelorstudium Lehramt, Masterstudium Lehramt). За упис на додипломске студије није потребно предзнање словенских језика, тј. кандидати који се одлуче за славистичке студије нису морали имати никакав претходни (наставни) контакт с било којим од словенских је-

${ }^{3}$ УП. Fachbereichsbericht WS 2016/17 - SS 2017 an der Universität Salzburg.

${ }^{4}$ У раду Г. Невекловског, од пре 30-ак година (1987), може се прочитати како је, уз русистику, сербокроатистика најатрактивнија на славистичким катедрама у Аустрији, те да се може студирати на свих пет универзитета (дакле, поред Беча, Граца и Клагенфурта, ту су још и Инзбрук и Салцбург)!

${ }^{5}$ У аустријском образовном (високошколском) систему тзв. наставнички студиј [Lehramtstudium] значи да студент бира две главне области [zwei Fächer], из којих по окончању студија може држати наставу у школи (нпр. Б/Х/С и немачки, или Б/Х/С и енглески итд.). 
зика. Додипломске студије, на свим славистичким институтима, обухватају три главне области: науку о књижевности (Literaturwissenschaft), науку о језику (Sprachwissenschaft) и културологију (Kulturwissenschaft). Ако већ није инкорпорирано у културологију, ${ }^{6}$ онда се овим трима областима придодају још и медиологија (медијске студије) и комуникологија (Medien- und Komm unikationswissenschaften).

2.3. Разлози за учење српског, одн. Б/X/C-a. Неколики су разлози због којих се студенти одлучују за учење српског, тј. Б/Х/С језика. Као што Карасињски и Савицка (2011) уочавају за Пољску, тако и у случају Аустрије постоје одређена стремљења у друштвено-политичком и економском сектору која су стимулисала (а и даље индукују) потребу за учењем нашег језика. Карасињски и Савицка, рецимо, бележе да су „догађаји на Балкану проузроковали раст интересовања за овај језички ареал”, па се закључило како „би имало смисла да се проблематика појединих јужнословенских језика покаже на ширем тлу” (2011: 218). Ни аустријска слика није битно другачија. Наиме, Аустрија се - најпре или напослетку - граничила са социјалистичком Југославијом, па су крвава дисолуција државе и ратни сукоб на овим просторима свакако имали још јачи одјек у овој земљи (у поређењу с неким другим западним земљама). С једне стране, у Аустрију су дошле бројне избеглице које су ту тражиле и налазиле уточиште из ратног вихора (посебно из Босне и Херцеговине). Отуда је - пре свега за потребе социјалних (али и других државних/бирократских) служби - нарастала потреба за онима који владају српскохрватским језиком и који су у стању да избеглим особама (које су у многим случајевима знале само матерњи језик) пренесу нужне информације у вези с њиховим боравком/останком и правима/обавезама у прибежишту. С друге стране, политичко-дипломатски, а доцније и пословно, Аустрија је била у мањој или већој мери присутна на Балкану (у војним и мировним мисијама, а у Босни и Херцеговини су се на позицији високог представника за БиХ налазила досад два Аустријанца), па је и то био један од разлога за већим интересовањем и, следствено, потребом за Б/Х/С-ом у Аустрији.

2.4. Тенденције везане за упис. На Институту за славистику у Грацу студира, ако се посматра просек у последњих десетак година, између 400 и 500 студената на свим годинама и нивоима студија (то значи и основне, некадашње четворогодишње и садашње трогодишње, као и мастерске студије). Године 2008. и 2009. тај број је досезао чак и преко шест стотина, после тога се тенденција усталила на поменутом просеку, да би од 2014. број студената био у извесном паду (те године нешто преко 400 студената на трима студијским смеровима славистике, а 2014/15. испод 380). По правилу највише је уписаних на смер русистике (нешто изнад $50 \%$ ), док се на сербокроатистици,

\footnotetext{
${ }^{6}$ Весна Цидилко (2011) скреће пажњу на то да у Немачкој националне филологије више не постоје, „да филологија у Немачкој практично не постоји, пре свега због тријумфалног и агресивног похода културологије". Ауторка с неодобравањем гледа на успон културолошких студија науштрб филолошких у Немачкој, указујући да „културологија фокусирајући се првенствено на социолошке аспекте, сматра у неким случајевима да може без историје и географије, тако да су ови наставни садржаји потиснути са нивоа семинара у оквир језичких вежби, где их треба некако 'успут’ интегрисати”' (2011: 199).
} 
одн. Б/X/C-у налази једна трећина (тј. нешто више од 30\%) и остатак на словенистици. На пример, у шк. 2012/13. години (зимски семестар) тај је однос изгледао овако:

\begin{tabular}{|l|l|l|l|}
\hline \multicolumn{1}{|c|}{ језик } & \multicolumn{1}{c|}{ руски } & \multicolumn{1}{c|}{ Б/Х/C } & \multicolumn{1}{c|}{ словеначки } \\
\hline $\begin{array}{l}\text { усмерење / ниво } \\
\text { студија }\end{array}$ & $\begin{array}{l}\text { Б / Ма / Дипл. } \\
\text { / наст }\end{array}$ & $\begin{array}{l}\text { Б / Ма / Дипл. } \\
\text { / наст }\end{array}$ & $\begin{array}{l}\text { Б / Ма / Дипл. / } \\
\text { наст }\end{array}$ \\
\hline број студената & 13466572 & 67114741 & 2311232 \\
\hline
\end{tabular}

Представљене податке можемо упоредити са онима на највећој аустријској славистици - на Институту за славистику у Бечу: ${ }^{7}$ у Бечу, примерице, додипломске студије ${ }^{8}$ у последњих десетак година просечно је похађало око 1.000 студената. $^{9}$ Опет се око 50\% студената одлучивало за руски као први језик, док се за Б/Х/С као први опредељивало неких 20\% студената славистике, што га је - према „тражњи” и занимању - позиционирало на убедљиво друго место.

Ове цифре нам јасно сведоче да постоји незанемарљив потенцијал, тј. заинтересованост студентске популације за учење (и изучавање) српског (Б/ X/C) језика у нашем најближем окружењу.

\section{3. Српски језик на Универзитету у Грацу.}

Зацртани циљеви и задаци: структура предавања и вежби

Курсеви који се организују показују усмереност (в. тачку 2.2) на језик, књижевност и културу. Поред лекторских вежби, о којима ће даље бити речи, треба истаћи да студенти који се одлуче за Б/X/C као главни језик имају прилике да слушају следеће курсеве (изостављамо подразумеване интродукторне и општеславистичке предмете типа Општи увод у словенски језике, културу и кьижевност, Увод у лингвистику итд.): Литерарна и културна историја Б/X/C-а I и II (са самосталном лектиром), Основе лингвистике Б/X/C u словеначког, Морфологија и синтакса Б/X/C, Усмени и писани израз у Б/X/Cy, Изабране теме из културологије Б/X/C-a, Изабране теме из лингвистике Б/X/C-a, Фонетика и фонологија Б/X/C-a, Граматичке структуре $5 / X / C-a$, Изабране теме из кьижевности Б/X/C-a, О землама Б/X/C-говорног подручја. На мастеру се још нуди и: Лингвистички семинар (номинализација и

7 Захваљујем др Емериху Келиху (Emmerich Kelih) на сусретљивости приликом прибављања потребних информација.

${ }^{8}$ Изостављени су, дакле, подаци о студентима мастерских и докторских студија, као и о онима који су на педагошком/наставничком смеру.

${ }^{9}$ Треба опет нагласити да се у Бечу могу студирати - као први - сви (књижевни) словенски језици, осим македонског и белоруског, што несумњиво утиче на бројност студената, чему доприноси свакако и чињеница да је реч о аустријској престоници и културном средишту коме гравитира огроман број младих. 
адјективизаиија у Б/X/C-y), Изабране теме из лингвистике Б/X/C-а (фактивни и пропозиционални садржај зависних клауза у Б/Х/С-у), Усмени и писани израз у Б/X/C-у: лексика и фразеологија.

Српски је лектор задужен за лекторске вежбе, и у просеку има 10 часова семестрално (половина норме!), који могу бити асиметрично распоређени (нпр. 6 у ЗС и 14 у ЛС и сл.). У случају „обичних” лекторских вежби на универзитетима у Аустрији, опет узимајући Грац као модел, постављају се нивои и циљеви у складу с европским референтним оквиром за познавање језика. Курс који српски лектор држи, некад самостално а некад у комбинацији с домицилним или хрватским разменским лектором, има једноставан назив $5 / X / C 1,2$ и 3 (у зависности од године студија). На првој се години студенти оспособљавају да усвоје језичке вештине, према поменутом референтном оквиру, на нивоу А2(/+), како у домену усменог изражавања, тако и у развоју писаног израза и разумевања прочитаног текста. Ради тога се - током првог и, још више, другог семестра - постепено повећава количина одговарајућег аудио-материјала и текстова (посебно актуелних материјала из медија, с интернета итд.), уз употребу иновативних наставних средстава, прилагођених студентима и припремљених према задатим циљевима. Тематски садржај лекција је заснован, како је речено, на референтном оквиру, што у мањој или већој мери кореспондира с постојећим уџбеницима српског језика за странце (коришћени су новосадски уџбеници Научимо српски 1 и 2 - Let's Learn Serbian $1 \& 2$ ). Конкретније речено - овако изгледа осмишљени план: консолидација основне граматике; проширење речника; учење одређених разговорних ситуација, дискутовање; стицање способности писања текстова; учење идиоматских карактеристика; ширење фонетске компетенције... ${ }^{10}$ Студент би - након одслушаног курса $5 / X / C 1$ - требало да је у стању да се споразуме у рутинским ситуацијама: да предочи своју личну историју и образовање, најближу околину и искаже оно што му је најнужније. На другој години, у оквиру предмета $5 / X / C 2$, наставља се започето: циљ је да студенти досегну ниво Б1(/+) (у све четири основне компетенције: слушање, читање, писање, говор), при чему се, пошто је реч о тзв. напредном нивоу, нешто већа пажња посвећује промовисању аутономије студената, као и усвајању метајезичких (а не само језичких) вештина. Напослетку, на трећој години (Б/X/C 3) курс је тако осмишљен да се даље усавршавају наведене четири језичке вештине као и језичка знања о одабраним темама из морфологије и синтаксе. На трећој години и лектор има већу слободу у одабиру тема, али и далеко веће могућности за разноврснију и интерактивнију наставу, будући да су полазници прешли преко тзв. прага знања и да се крећу од напредног ка самосталном (Ц) нивоу. Како се и уџбеници српског језика за странце окончавају на Б1/Б2 нивоу, утолико је већа одговорност на лектору у погледу конципирања лекторских вежби, чиме долази до изражаја и његова креативност. Оквирно се могу идентификовати следеће главне теме курса: културно наслеђе и до-

${ }^{10}$ В. више у институтском билтену и на сајту Института за славистику (https://slawistik.unigraz.at/de/). 
гађаји, модерни манири, путовања, конзумеризам, стереотипи и предрасуде, однос између природе и технологије, маркетинга и комуникација, проблем (заштите) животне средине итд., док се у области граматике учвршћује стечено знање на морфолошком и морфосинтаксичком нивоу (конгруенција с бројевима, валенца глагола, именица и придева...), уз обрађивање текстуалних феномена (различите врсте текстуалних конектора као површинских средстава остваривања кохезије и сл.).

Из искуства нам је познато да се лектору могу у његовој 2. или 3. години ангажмана у Грацу понудити да организује и одржи додатне курсеве, који могу обухватати нека од поменута три домена - из лингвистике, књижевности, културе. Тако се тај додатни курс може тицати нпр. српске, одн. југословенске кинематографије који подразумева како пројекцију филмова тако и пратећи коментар. Посебно се може истаћи заинтересованост студената за југословенски црни талас који је наишао на добру рецепцију, пре свега, наравно због врхунских филмских остварења, али и због упознавање шире друштвено-историјске слике која је омогућила студентима да узму активније учешће у дискусијама након одгледаних филмова. Управо овај случај показује да разменски лектор - по правилу студент српске филологије (дакле, српског језика и књижевности) - мора познавати, тј. да се мора припремити и за оне области за које није примарно факултетски образован и усмерен, и да би требало да има осећај за контекстуализацију одређених културних феномена који се, по правилу, и студентима у иносредини чине најинтересантнијим и за које они показују већу жељу да их боље упознају. Наравно, додатни се курсеви могу организовати и из области књижевности (нпр. преглед најзначајних дела српске/југословенске књижевности, или драме, или још уже, нпр. међуратног романа) или се пак проблематизовати нека од лингвистичких питања - али то је већ оно што би лектор требало лакше да припреми будући да је то предмет његових изворних студија. Дакако, и за то је - у зависности од теме, искуства лектора и његовог знања и интересовања - потребно време, тако да у овом случају лектор треба озбиљно да се подухвати припреме часова и осмишљавања начина на које ће изложити (додатно) градиво за које се одлучи.

Ваљало би сада рећи нешто и о другом институту на коме је ангажован лектор из Србије. Наиме, и на Универзитету у Бечу и на Универзитету у Грацу, како је у тачки 2.1 назначено, постоји преводилачки департман: Институт за теоријско и примењено преводилаштво (ИТПП) у Грацу и Центар за преводилаштво у Бечу, на којима се такође може учити српски, тј. Б/X/C у комбинацији с немачким и још једним (трећим) језиком. ${ }^{11}$

У Грацу се на Институту за транслатологију, поред немачког као страног, може похађати настава из још 12 језика, ${ }^{12}$ од којих је српски, одн. Б/Х/C један у понуди. Програм додипломских студија на ИТПП-у је конципиран

\footnotetext{
${ }^{11}$ Могуће је одлучити се и само за 2 језика, матерњи и један страни, али је то ређи случај.

12 Дакле, поред немачког, ту су још и арапски, Б/X/C, енглески, француски, италијански, руски, словеначки, шпански, турски, мађарски, као и (аустријски) језик глувонемих (Österreichische Gebärdensprache).
} 
тако да омогући усвајање основних научних знања и метода (а) за анализу и промишљање интеркултуралне и транскултуралне комуникације, као и за (б) обављање послова на међународном нивоу или у оквирима мултикултуралних и вишејезичних институција, фирми и организација. ИТПП, као и други транслатолошки институти, поставља тежиште студија на стицање следећих вештина и знања: упознавање с основама интер/транскултуралне комуникације и транслатологије; усмена и писана транскултурална комуникација на матерњем језику и на два страна језика; одговарајуће знање о друштвеним, политичким, културним и економским особеностима земаља чији се језик учи итд. ${ }^{13}$

Наш лектор, да би имао половину норме, тј. 10 часова, мора држати наставу и на Институту за транслатологију (ИТПП), што сматрам да је добра околност, будући да на тај начин, прво, има прилику да се упозна и с радом института какви су код нас још ретки, и стекне важна искуства, и друго, важније, што ће на тај начин имати приступ још већем броју студената. Оријентација института је ка већ поменутој транскултуралној комуникацији, што се постиже тиме што студенти уче, дакле, три радна језика (тј. два страна, уз матерњи) и оспособљавају се да различите садржаје (у разним комуникационим ситуацијама) учине разумљивим различитој публици, која говори различите језике и припада различитим културама. Отуда не чуди што лекторски курс носи назив: Б/X/C - Језичка, текстуална и културна компетенција 1, 2, 3 и 4. Тако се, поред учења основних морфолошких и синтаксичких структура и лексике, инсистира и на ширем знању о културном контексту (друштвени, историјски, политички, па чак и економски аспекти). Према томе, након завршетка курса $5 / X / C$ - Језичке, текстуалне и културне компетенције студент би требало да поседује следеће вештине: (а) знање језика - рецептивне природе: читање, слушање (што значи да могу анализирати структуру аутентичних текстова (писмено, усмено) и различите врсте текстова) и продуктивне природе (што значи да су студенти у стању да произведу кохерентан писмени или усмени текст, који задовољава услове своје реализације у различитим комуникативним ситуацијама), ${ }^{14}$ (б) културне компетенције: студенти су у стању да идентификују, дефинишу и опишу географску, економску, историјску, етничку, верску, политичку и друштвену ситуацију Б/Х/С културног и језичког простора.

По окончању 4. курса очекује се да су студенти боље упознати с карактеристикама језика и дате културне области (везане за тај језички ареал), што је предуслов за адекватно језичко и транскултурално деловање; затим не више само да су у стању идентификовати, дефинисати и описати културне појаве, већ и да разумеју процесе који су довели до културних образаца

\footnotetext{
${ }^{13}$ В. више у програмским циљевима студија на сајту ИТПП-а (https://translationswissenschaft. uni-graz.at/) и у билтену Mitteilungsblatt der Karl-Franzens-Universität Graz, Curriculum für das Bachelorstudium Transkulturelle Kommunikation.

${ }^{14}$ Иако су рецептивне и продуктивне језичке вештине истакнутије, не занемарују се ни тзв. структурне вештине, што значи да је важно и да студенти могу свесно применити своје познавање језичких структура (у анализи).
} 
размишљања и понашања; и можда најважније: да су у стању да разумеју и превазиђу препреке и потешкоће у суочавању са другом културом управо на основу познавања и употребе одговарајућих стратегија. ${ }^{15}$

Други тип лекторских вежби који се реализује на овом институту - вежбе из превођења, тумачења, специјализованог превођења, консекутивног и симултаног конференцијског превођења (нпр. B/K/S: Translatorische Basiskompetenz I, B/K/S: Translatorische Basiskompetenz I - Textkompetenz, B/K/S: Verhandlungsdolmetschen, $\mathrm{B} / \mathrm{K} / \mathrm{S}$ : Übersetzen - Wirtschaft und Tourismus $(\mathrm{B} /$ $\mathrm{K} / \mathrm{S}-\mathrm{D}), \mathrm{B} / \mathrm{K} / \mathrm{S}$ : Analyse- und Dolmetschtechniken, B/K/S: Analyse- und Übersetzungstechniken (B/K/S-D), B/K/S: Konferenzdolmetschen (konsekutiv), B/ $\mathrm{K} / \mathrm{S}$ : Konferenzdolmetschen (simultan), B/K/S: Kommunaldolmetschen, B/K/S: Übersetzen - Wirtschaft und Tourismus (D-B/K/S), а на мастеру још и B/K/S: Public Service Interpreting I и II) - наши лектори не изводе, јер се (оправдано) сматра да је за ову врсту лекторских вежби нужна специјализација у области превођења и тумачења. (Можда ће се ово изменити након отпочињања с радом мастерских студија из транслатологије на појединим универзитетима у Србији.) Оно што је, међутим, битно нагласити је да се на овом институту може узети Б/X/C и као матерњи језик, што значи да лектор онда изводи вежбе у оквиру тзв. предмета B/K/S: Mutter-/Bildungssprache: Textanalyse und Textproduktion, што опет за собом повлачи другачије осмишљавање курса.

4. Закључцุи и предлози. Аустријска славистика, где смо као узор највише користили сазнања о институту (институтима) из Граца као и четворогодишње искуство разменског лектора, показује да одолева редукционим политикама својственим нпр. Немачкој (уп. Марковић 2007, Цидилко 2011), која слови за највећи славистички, па тиме и сербокроатистички, несловенски простор где се може студирати српски језик, тј. Б/Х/С. Пад интересовања за славистику, па тиме и српски, тј. Б/Х/С у последњих неколико година ипак постоји, но то је и очекивано имајући у виду изненађујући скок који је наступио средином двехиљадитих у Аустрији, када је много оних који су у ратним деведесетим као деца избегли са својим породицама у Аустрију стасали за студије. Даље, приметно је да на славистици уопште, па тиме и сербокроатистици унутар ње, а још изразитије на транслатолошким студијама где постоји Б/X/C, културологија бива све доминантнија (што ипак не значи да на славистичким катедрама културолошки аспект подређује себи ускофилолошки). ${ }^{16}$ То би свакако требало да имају у виду и наши факултети где постоје транслатолошки мастерски програми (или за српски као други/ страни), и да поклоне већу пажњу управо овим културним феноменима, који су и интересантни страним студентима и (темељно) инкорпорирани у студијске програме. Према томе, лекторски рад обухвата не само подучавање српског као страног језика него и презентовање одређених културних теко-

${ }^{15}$ В. више о томе у: Mitteilungsblatt der Karl-Franzens-Universität Graz, Curriculum für das Bachelorstudium Transkulturelle Kommunikation.

${ }^{16}$ Ако се проучи историјат нпр. славистике у Грацу, видеће се да је тамо одувек постајала јака тенденција ка културолошким питањима, и да је од самих почетака уз, наравно, филологију релевантно поље истраживања. 
вина, достигнућа нације из које лектор потиче/долази. Што значи да поред доброг познавања језика (граматике) и књижевности, и умећа да се то знање пренесе (на вежбама), лектор треба да буде стручан и за одређене културолошке предмете, мора бити у додиру са савременим (културним) токовима, али и учинити све да помогне, макар на микроплану, да се оствари контакт с културом домаћина, тј. земље у којој се налази.

Такође, ако пребацимо фокус на преводилачке институте, треба и у оквиру наших мастерских транслатолошких програма можда понудити такве садржаје које би наши разменски лектори могли искористити, по одласку, у иностранству и тако евентуално повећати свој фонд часова.

Повратно, из матичне земље ка оној у којој се лектор налази такође треба да тече подршка и помоћ у сврху промовисања нашег језика и културе на факултету/универзитету где се налази лектор: могу се организовати предавања гостујућих предавача, професора с наших универзитета, књижевника, културних делатника... У сврху унапређења квалитета поучавања језика и књижевности, Министарство би требало редовно да опрема лекторате (и оне који јесу у његовој надлежности и оне који то нису, јер то је начин да се наш језик и књижевност приближе страним студентима) не само неопходним уџбеницима и књигама, како стручном литературом, тако и актуелном белетристичком продукцијом, него и аудио-визуелним средствима: дисковима с наснимљеним материјалом, видео-дидактичким материјалом, филмовима и сл. Лектори би требало да имају директну комуникацију с матичним факултетима/катедрама (с којих долазе) и њихову помоћ/подршку, како ради решавања неких у том моменту битних питања тако и ради усавршавања. Корисно би било, чини се, не само такво вертикално (екстерно-интерно) повезивање, дакле од матичне земље (Министарство или матични факултет/катедра) ка лектору у иностранству, него и - ако постоји могућност - хоризонтално повезивање лектора српског језика и књижевности, дакле оних који су у некој (иностраној) земљи (или на једном језичком подручју), јер различитим индивидуалним искуствима могу допринети усавршавању, побољшању наставе (будући да раде у сличним условима/околностима, са истим матерњим говорницима који уче српски...).

На самоме крају, нема сумње да је један од најефикаснијих начина сарадње, што би свакако унапредило и статус српског језика на славистичким студијама/транслатологији у иностранству, а на чему држава, тј. Министарство (као и универзитети у Србији) мора посебно да се ангажује - јесте додељивање страним студентима (уп. Бањанин 2007: 273) већег броја (i) стипендија за усавршавање српског језика на летњим школама (Летьа школа српског језика на Новосадском универзитету или Скуn слависта МСЦ-а на Београдском универзитету) или (iі) одређеног броја стипендија за једносеместрални или двосеместрални боравак на филозофском, односно филолошком факултету, у Новом Саду, Нишу, Крагујевцу или Београду. 


\section{ЛИТЕРАТУРА}

Бањанин 2007: Љ. Бањанин, Лекторати српско-хрватског / српског језика у Италији: историјат, стање и перспективе, у: М. Дешић (гл. ур.), Српски као страни језик у теорији и пракси: зборник радова, Београд: Министарство просвете и спорта РС, Филолошки факултет, Центар за српски као страни, 267-276.

Бугарски 2016: R. Bugarski, Jezici u potkrovlju, Beograd: Biblioteka XX vek.

Карасињски/Савицка 2011: А. Карасињски, И. Савицка, Српски језик на Универзитету Никола Коперник у Торуњу, у: В. Крајишник (гл. ур.), Сpnски као страни језик у теорији и пракси 2: тематски зборник радова, Београд: Филолошки факултет, 217-228.

Крајишник 2014: В. Крајишник, Лекторати српског језика, у: С. Танасић (ур.), Зборник Института за српски језик САНУ 2. Српски језик и актуелна питања језичке политике, Београд, 217-226.

Марковић 2007: Ж. Марковић, О положају србистике на универзитетима у Немачкој, у: Ј. Вучо (прир.), Савремене тенденичије у настави језика и књижевности, Београд: Министарство за науку и заштиту животне средине, Филолошки факултет, 412-417.

Невекловски 1987: G. Neweklowsky, Austrijska lingvistička jugoslavistika danas, Нови Сад: Зборник Матице српске за филологију и лингвистику $\mathrm{XXX/1,} \mathrm{Нови} \mathrm{Сад,} \mathrm{85-94.}$

Степанов/Николић 2010: С. Степанов, М. Николић, Статус српског језика на аустријским катедрама, Београд: Славистика XIV, Београд: 299-308.

Цидилко 2011: В. Цидилко, О концепту наставе српског језика и књижевности у Немачкој, у: В. Крајишник (гл. ур.), Српски као страни језик у теорији и пракси 2: тематски зборник радова, Београд: Филолошки факултет, 197-204.

\section{Извори с интернета}

http://www-gewi.uni-graz.at/slaw

http://www.slawistik.ac.at/

http://www.slavistenverband.de

http://www.uni-graz.at/itat/

http://slawistik.univie.ac.at/

http://transvienna.univie.ac.at/

http://www.wu.ac.at/slawisch/

www.uni-salzburg.at/slaw (Fachbereichsbericht WS 2016/17 - SS 2017 Fachbereich Slawistik an der Universität Salzburg - 50Jahre Slawistik)

https://static.uni-graz.at/fileadmin/gewi-institute/Translationswissenschaft/Curricula_neu/BA_TKK.pdf (Mitteilungsblatt der Karl-Franzens-Universität Graz, Curriculum für das Bachelorstudium Transkulturelle Kommunikation) 


\title{
SERBISCHE SPRACHE AN DEN UNIVERSITÄTEN IN ÖSTERREICH
}

\author{
Zusammenfassung
}

Dieser Beitrag beschäftigt sich mit dem institutionellen und pädagogischen Rahmen/den Curricula an österreichischen slawistischen und translatologischen Instituten, an denen man Serbisch (bzw. $\mathrm{B} / \mathrm{K} / \mathrm{S}$ ) studieren kann, wobei ein besonderes Augenmerk auf das Institut für Slawistik und das Institut für Translationswissenschaft der Karl-Franzens Universität (Graz) gelegt werden sollte. Daneben werden Tendenzien in der Immatrikulationspolitik der betrachteten Fakultäten/Institute beschrieben. Der Schwerpunkt dieses Beitrags bezieht sich auf die Fragen (und Probleme), mit denen Austauschlektoren für serbische Sprache bei der Ankunft an den jeweiligen österreichischen Lehrstühlen konfrontiert werden. Im letzten Abschnitt werden Vorschläge und Ideen für die Lektorarbeit präsentiert sowie einige Schritte, die zuständige serbische Institutionen vornehmen könnten/sollten, um den Status der serbischen Sprache und Lektorate im Ausland zu verbessern und erfolgreicher zu machen.

Schlüsselwörter: Serbisch als Fremdsprache, serbische Lektorate (in Österreich), Herausforderungen des Lektorenberufs. 